\title{
PENGARUH STARTER BAKTERI ASAM LAKTAT PROBIOTIK TERHADAP PERUBAHAN KIMIAWI DAN MIKROBIOLOGIS RUSIP
}

\author{
[Influence of Probiotic Lactic Acid Bateria Starter on the Chemical \\ and Microbiological Changes of Rusip]
}

\author{
Pebry Aisyah Putri Batubara, Desniar*, dan Iriani Setyaningsih \\ Departemen Teknologi Hasil Perairan, Fakultas Perairan dan IImu Kelautan, Institut Pertanian Bogor, Bogor
}

Diterima 15 Mei 2018 / Disetujui 16 Januari 2019

\begin{abstract}
Rusip is one of the fish fermentation products. Traditional rusip made by Bangka Belitung community do not have a specific standard which leads to the high variety of quality. One of the efforts to improve the quality of rusip is the addition of lactic acid bacteria $(L A B)$ as a starter culture. This research aims to study the effect of the addition of starter culture combinations on the chemical and microbiological changes of the rusip and to obtain the best combination of $L A B$ starters in rusip fermentation. This research used anchovy fish (Stolephorus $s p$ ) and $5 \%$ of $L A B$ starter combination consisting of Lactobacillus plantarum SK(5) and L. plantarum NS(5), L. plantarum NS(5) and L. plantarum NS(9) and L. plantarum NS(9) and L. plantarum SK(5) 5\%. In addition, $5 \%$ of salt $(w / w)$ and $5 \%$ of palm sugar $(w / w)$ were added. The fermentations were conducted for 8 days. The research were conducted in three stages: 1) starter culture preparation; 2) raw material (fish) preparation; and 3) application of starter culture during rusip fermentation. The results showed that raw materials contained a total microbe of $3.0 \times 10^{4} \mathrm{CFU} / \mathrm{g}$, non detectable levels of $L A B, 6.54 \mathrm{of} \mathrm{pH}$ and $20.40 \mathrm{mg} \mathrm{N} / 100 \mathrm{~g}$ of total volatile bases (TVB). After fermentation, the rusip contained total $L A B$ of $7.64-9.24 \mathrm{log} C F U / g, 0.86-3.98 \%$ of total lactic acid, $4.22-6.36$ of $\mathrm{pH}, 0.32-1.39$ of free amino acid and $5.34-5.44 \%$ of salt. The best rusip was produced by a combination of L. plantarum SK(5) and L. plantarum NS(5) and contained $12.36 \mathrm{~g} / 100 \mathrm{~g}$ of total amino acid.
\end{abstract}

Keywords: lactic acid bacteria, probiotic, rusip, starter

\section{ABSTRAK}

Rusip adalah salah satu produk fermentasi ikan. Proses pembuatan rusip secara tradisional yang di lakukan oleh masyarakat Bangka Belitung belum memiliki standar sehingga mutu produk yang dihasilkan tidak seragam. Salah satu upaya meningkatkan mutu produk yaitu dengan penambahan kultur starter bakteri asam laktat (BAL). Tujuan penelitian ini yaitu mempelajari pengaruh penambahan kombinasi starter terhadap perubahan kimiawi dan mikrobiologis rusip dan menentukan kombinasi starter terbaik. Penelitian ini menggunakan ikan teri (Stolephorus sp), starterBAL asal bekasam yaitu Lactobacilus plantarum SK(5) dengan L. plantarum NS(5), L. plantarum NS(5) dengan L. plantarum NS(9) dan L. plantarum NS(9) dengan L. Plantarum SK(5) sebanyak 5\%. Penambahan garam dan gula aren masing-masing 5\% (b/b). Waktu fermentasi 8 hari. Penelitian ini terdiri dari tiga tahapan, yaitu 1) pembuatan kultur starter; 2) preparasi bahan baku ikan; dan 3) fermentasi rusip. Bahan baku yang digunakan menunjukkan total mikroba $3,0 \times 10^{4} \mathrm{CFU} / \mathrm{g}$ (coloni forming units per gram), total BAL tidak terdeteksi, $\mathrm{pH} 6,54$ dan total volatile bases (TVB) $20,40 \mathrm{mgN} / 100 \mathrm{~g}$. Setelah rusip di fermentasi, karakteristik mikrobiologis dan kimiawi meliputi total BAL 7,64-9,24 log CFU/g, total as am titrasi 0,86-3,98\%, pH 4,22-6,36, absorbasi as am amino bebas $0,32-1,39$ dan kadar garam 5,34-5,44\%. Rusip terpilih adalah kombinasi Lactobacilus plantarum SK(5) dan Lactobacilus plantarum NS(5) mengandung total asam amino 12,37 g/100 g.

Kata kunci: bakteri asam laktat, probiotik, rusip, starter

\section{PENDAHULUAN}

Rusip merupakan salah satu produk fermentasi ikan yang berasal dari Indonesia yaitu Kepulauan Bangka Belitung. Rusip dikonsumsi sebagai cam-

*Penulis Korespondensi:

E-mail: desniar2013@gmail.com puran sambal dan dimakan bersama nasi, lalapan atau sebagai lauk. Rusip umumnya terbuat dari ikan teri (Stolephorus sp), garam $10-25 \%$, gula aren $10 \%$ dan selanjutnya difermentasi secara anaerob selama 7-14 hari (Sastra, 2008). Liu et al., (2011) mengemukakan bahwa beberapa manfaat pada produk fermentasi yaitu meningkatkan nilai keamanan pa- 
ngan. Hal ini didukung oleh Khan et al. (2010) yang mengemukakan bahwa bacteriocin dalam produk fermentasi digunakan untuk pengawetan produk daging dan sayuran dengan cara menghambat bakteri patogen dan pembusukan makanan.

Produk fermentasi secara tradisional memiliki kelemahan yaitu mutu produk yang tidak seragam, jenis mikroba yang tumbuh sangat banyak dan sulit terkontrol, populasi awal BAL yang rendah menyebabkan bakteri pembusuk dan bakteri patogen tumbuh cepat mendahului pertumbuhan BAL (Kusmarwati et al., 2011). Kelemahan ini perlu diperbaiki untuk menghasilkan rusip dengan mutu yang baik dan seragam, yaitu salah satunya dengan penambahan kultur starter bakteri asam laktat pada proses fermentasi. Beberapa penelitian menunjukkan bahwa penambahan starter BAL dapat meningkatkan mutu produk. Kusmarwati et al. (2011) membuktikan penambahan starter Pediococcus acidilactis F-11 dapat meningkatkan total BAL dan menurunkan total coliform serta mempersingkat waktu fermentasi rusip menjadi 9 hari, Koesoemawardani dan Yuliana (2009) melaporkan penambahan Streptococcus sp mampu menghasilkan $\mathrm{pH}$, total BAL, kadar garam, dan kandungan total volatile nitrogen (TVN) lebih tinggi dibandingkan dengan fermentasi spontan selama 7 hari fermentasi. Koesoemawardani et al. (2013) melaporkan rusip yang difermentasi dengan penambahan starter campuran yaitu Streptococcus, Lactococcus dan Leuconostoc sebanyak $2 \%$ memiliki nilai ph, total asam laktat dan bakteri asam laktat lebih baik dibandingkan dengan rusip secara spontan. Utami (2016) menambahkan Lactobacillus plantarum SK(5) pada rusip menghasilkan produk rusip dengan waktu fermentasi lebih singkat yaitu 7-8 hari.

Desniar et al. (2012) berhasil mengisolasi 62 bakteri asam laktat, diantaranya Lactobacillus plantarum SK (5) asal bekasam ikan seluang (Rasbora argerotaenia), L. plantarum NS(5) dan L. plantarum NS(9) asal bekasam ikan nila (Oreochromis niloticus) Sumatera Selatan. Ketiga bakteri tersebut menghasilkan senyawa antimikroba terhadap E. coli, S. typhimurium, S. aureus, B. cereus, dan L. monocytogenes (Desniar et al., 2016). Bakteri tersebut dapat dijadikan sebagai kandidat probiotik (Syafiqoh, 2014). Bakteri L. plantarum tergolong bakteri probiotik karena dapat bertahan pada pH lambung, $\mathrm{pH}$ usus dan garam empedu serta sifatnya tidak patogen (Nurnaafi et al., 2015). Berbagai penelitian telah menunjukkan bahwa probiotik dapat memiliki efek antihipertensi (Zhang dan Zhang, 2013), efek penurun kolesterol (Bosch et al., 2014), dan efek antidiabetes (Gomes et al., 2014).

Starter pada rusip sejauh ini hanya menggunakan satu jenis bakteri asam laktat. Penggunaan starter tunggal umumnya mempunyai resiko yang tinggi karena kondisi harus optimum sehingga untuk mengurangi kegagalan dapat digunakan starter cam- puran. Aplikasi dari BAL probiotik Lactobacillus plantarum SK(5), L. plantarum NS(9) dan L. plantarum NS(5) asal bekasam masih sangat terbatas. Salah satu aplikasinya adalah sebagai starter sehingga dapat dikembangkan untuk pembuatan rusip. Penggunaan kadar garam yang tinggi juga mengakibatkan hipertensi bagi pengkonsumsinya sehingga dengan penambahan starter kombinasi BAL probiotik asal bekasam dapat menekan penggunaan kadar garam yang tinggi dan tetap menghasilkan rusip yang bermutu baik. Tujuan penelitian ini yaitu mempelajari pengaruh penambahan kombinasi starter terhadap perubahan kimiawi dan mikrobiologis rusip dan menentukan kombinasi starter terbaik. Manfaat penelitian ini untuk memberikan informasi mengenai rusip dengan menggunakan kombinasi starter BAL probiotik. Hasil penelitian ini diharapkan dapat menjadi dasar untuk penelitian lainnya, penerapan pada produk yang terkait dan peningkatan konsumsi pangan fungsional.

\section{BAHAN DAN METODE}

\section{Bahan}

Bahan utama yang digunakan adalah ikan teri (Stolephorus commersoni) segar yang diperoleh dari Pelabuhan Ratu, garam dan gula aren dari pasar Anyar, Lactobacilius plantarum SK(5), Lactobacilius plantarum NS(9) dan Lactobacilius plantarum NS(5) dari koleksi Desniar (2012). Penelitian ini dilaksanakan pada bulan Oktober 2017 hingga Februari 2018 bertempat di Laboratorium Mikrobiologi Hasil Perairan, Laboratorium Biokimia Hasil Perairan, Laboratorium Terpadu Fakultas Perikanan dan IImu Kelautan, Laboratorium Pusat Akademik Universitas (PAU), Laboratorium Terpadu Departemen IImu Nutrisi dan Teknologi Pakan, Fakultas Peternakan, Institut Pertanian Bogor.

\section{Pembuatan kultur starter}

Pembuatan kulturstarter mengacu pada Koesoemawardani dan Yuliana (2009). Bakteri asam laktat probiotik asal bekasam dilakukan penyegaran. Kultur bakteri kemudian dipisahkan antara biomassa dan supernatannya menggunakan sentrifuse kecepatan $1500 \mathrm{G}$ dengan suhu $4^{\circ} \mathrm{C}$ selama 15 menit dalam keadaan steril. Biomasa diinokulasikan ke dalam Buffer Pepton Water steril dengan volume semula. Jumlah sel bakteri dihitung menggunakan metode tuang.

\section{Preparasi bahan baku}

Ikan teri dibersihkan dari kotoran yang menempel dan dilakukan analisis total mikroba dan TVB (AOAC, 2005), kemudian $100 \mathrm{~g}$ ikan disterilkan dengan cara dicelupkan (blanching) kedalam air mendidih $\left(94-98^{\circ} \mathrm{C}\right)$ selama 1 detik mengacu pada 
metode Afrianto et al. (2014) yang dimodifikasi. Ikan dimasukkan kedalam botol jar bertutup kemudian ditambahkan gula aren dan garam masing-masing $5 \%(\mathrm{~b} / \mathrm{b})$. Campuran ikan, gula dan garam dianalisis total mikroba, total bakteri asam laktat dan $\mathrm{pH}$ (Sudarmadji et al., 1997).

\section{Pembuatan rusip}

Pembuatan rusip mengacu pada Utami (2016) yang dimodifikasi dari starter tunggal menjadi starter campuran. Setelah dipreparasi, ikan diberi 3 perlakuan penambahan kombinasi kultur starter yaitu perlakuan A (Lactobacilus plantarum SK(5) dengan $L$. plantarum NS(5)), B (L. plantarum NS(5) dengan $L$. plantarum NS(9)) dan C (L. plantarum SK(5) dengan L. plantarum $\mathrm{SN}(9)$ ) dengan konsentrasi masingmasing 5\% (b/v) kemudian ditutup rapat, diperam selama 8 hari pada suhu ruang. Analisis dilakukan pada hari ke-0, 2, 4, 6 dan 8 meliputi total bakteri asam laktat, total asam laktat (AOAC, 2005), $\mathrm{pH}$ (AOAC, 2005), asam amino bebas dengan Ninhidrin dan kadar garam (AOAC, 2005). Analisis kadar garam dilakukan pada hari ke-8 fermentasi. Rusip terpilih dianalisis komposisi asam aminonya menggunakan high performance liquid cromatography (HPLC) (AOAC, 2005).

\section{Analisis data}

Data yang diperolehdiolah menggunakan Microsoft Excel 2013 untuk menentukan rerata dan standar deviasi (Mean \pm SD). Hasil pengolahan data disajikan dalam bentuk tabel dan grafik serta dianalisis secara deskriptif.

\section{HASIL DAN PEMBAHASAN}

\section{Kultur starter}

Kultur starter yang digunakan pada penelitian ini adalah Lactobacilus plantarum SK(5) sebesar $3,0 \times 10^{9} \mathrm{CFU} / \mathrm{ml}$, L. plantarum NS(5) sebesar $4,3 \mathrm{x}$ $10^{9} \mathrm{CFU} / \mathrm{ml}$ dan L. plantarum NS(9) sebesar $4,3 \times 10^{9}$ $\mathrm{CFU} / \mathrm{ml}$. Jumlah kolonitelah memenuhi syarat untuk digunakan sebagai kultur starter. Jumlah bakteri asam laktat pada produk yang baik dikonsumsi dan baik untuk kesehatan berkisar antara $10^{7}-10^{9} \mathrm{CFU} /$ ml. Françoise (2010) menyatakan bahwa penggunaan BAL strain yang berbeda dari $L$. plantarum, $L$. acidophilus, Pediococcus halophilus dan $P$. acidilactici telah diujicobakan pada produk fermentasi berbahan baku ikan dan telah berhasil yang ditandai dengan menurunnya $\mathrm{pH}$ pada produk tersebut dengan cepat.

\section{Karakteristik bahan baku}

Ikan merupakan sumber protein hewani yang banyak dimanfaatkan karena kandungan gizinya yang tinggi. Kesegaran ikan sangat menentukan produk akhir olahan ikan. Semakin baik kualitas bahan bakunya maka kualitas rusip yang dihasilkan akan semakin baik pula. Karakteristik bahan baku dan teri blansir disajikan pada Tabel 1 .

Proses blansir pada bahan baku sebelum digunakan dapat menurunkan jumlah total mikroba. Kualitas bahan baku diukur berdasarkan tingkat kesegarannya. Salah satu parameter kesegaran ikan dapat diukur dari nilai jumlah total mikroba bahan baku. Nilai total mikroba teri basah sebesar $3,9 \times 10^{5}$

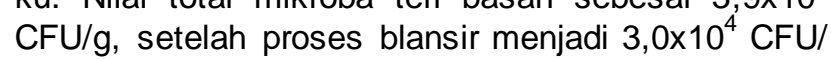
$\mathrm{g}$ dan telah memenuhi syarat ikan segar. Suhu blansir mampu menghambat atau menghentikan aktivitas enzim dan mendenaturasi protein ikan, namun tidak dapat membunuh semua bakteri pembusuk. Afrianto et al. (2014) melaporkan bahwa filet ikan tagih (Mystus sp) dengan teknik blansir $80^{\circ} \mathrm{C}$ selama tiga menit memberikan umur simpan lebih lama hingga hari ke-13 dan total coliform yang rendah dari $7,2 \times 10^{5}$ menjadi $2,0 \times 10^{5} \mathrm{CFU} / \mathrm{g}$. Total BAL tidak terdeteksi pada teri blansir. Hal ini disebabkan suhu blansir $\left(94-98^{\circ} \mathrm{C}\right)$ membunuh BAL pada bahan baku, sehingga $B A L$ yang berperan dalam produk rusip adalah BAL probiotik yang sengaja dicampurkan. Bakteri asam laktat seperti L. plantarum tumbuh pada suhu optimum $30-38^{\circ} \mathrm{C}$.

Tabel 1. Karakteristik bahan baku dan teri blansir

\begin{tabular}{lccc}
\multicolumn{1}{c}{ Analisis } & $\begin{array}{c}\text { Teri } \\
\text { Basah }\end{array}$ & $\begin{array}{c}\text { Teri } \\
\text { Blansir }\end{array}$ & $\begin{array}{c}\text { Syarat lkan } \\
\text { Segar }\end{array}$ \\
\hline $\begin{array}{l}\text { Total mikroba } \\
\text { (CFU/g) }\end{array}$ & $3,9 \times 10^{5}$ & $3,0 \times 10^{4}$ & $<5,0 \times 10^{5 *}$ \\
$\begin{array}{l}\text { Total BAL } \\
\text { (CFU/g) }\end{array}$ & - & 0 & - \\
pH & - & $6,54 \pm 0,02$ & $>6,2^{* *}$ \\
TVB (mg N/100g) & $20,40 \pm 0,2$ & - & $<30^{\star * *}$ \\
\hline $\begin{array}{l}\text { Keterangan: }{ }^{*} \mathrm{BSN}^{\mathrm{b}} \\
\text { (2009); }{ }^{* \star} \text { Khalafalla et al., } 2015 ;{ }^{* \star *} \text { Cheng }\end{array}$
\end{tabular}

\section{Total bakteri asam laktat (BAL)}

Bakteri asam laktat sangat berperan penting dalam proses fermentasi. Sifat terpenting dari BAL adalah kemampuannya untuk memfermentasi gula menjadi asam laktat. Fermentasi dapat terjadi karena adanya aktivitas mikroba penyebab fermentasi pada substrat organik yang sesuai. Perubahan total bakteri asam laktat disajikan pada Gambar 1 .

Total BAL awal fermentasi pada ketiga perlakuan berkisar 7,65-7,80 log CFU/g, meningkat pada fermentasi hari ke-2 sebesar 9,25 log CFU/g pada perlakuan A (Lactobacilus plantarum SK(5) dengan L. plantarum NS(5)), 9,22 log CFU/g pada perlakuan B (Lactobacilus plantarum NS(5) dengan L. plantarum NS(9)) dan 8,84 log CFU/g pada perlakuan $\mathrm{C}$ (Lactobacilus plantarum NS(9) dengan L. plantarum SK(5)). Jumlah total BAL perlakuan A dan B mengalami penurunan sampai hari ke-8. Jumlah koloni mikroba pada perlakuan $\mathrm{C}$ mengalami peningkatan 
hingga fermentasi hari ke-6 sebesar 9,24 log CFU/g dan kembali menurun di fermentasi hari ke-8.

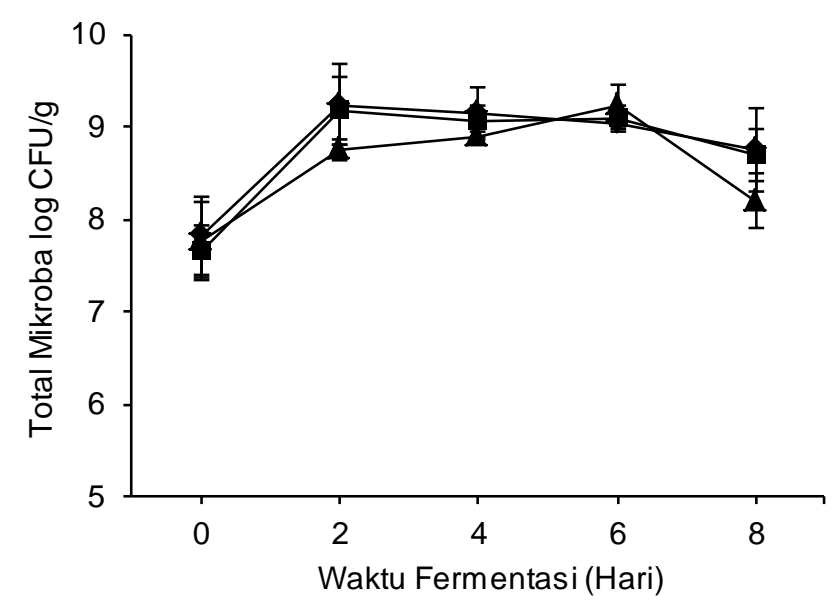

Gambar 1. Perubahan total BAL dengan penambahan starter $\mathrm{A}(\bullet), \mathrm{B}(\boldsymbol{\bullet})$ dan $\mathrm{C}(\boldsymbol{\Delta})$

Jumlah total BAL rusip pada hari ke-2 dengan penambahan perlakuan A lebih tinggi dibandingkan dengan penambahan starter kombinasi lainnya. Kurnasih (2016), total BAL tertinggi pada hari kedua yaitu 9,04 log CFU/g kemudian menurun diakhir fermentasi hari ke-12. Hal ini disebabkan penambahan kombinasi BAL, tumbuh maksimal pada hari ke-2 sebab nutrisi yang dibutuhkan untuk pertumbuhan bakteri tersebut masih tersedia dengan baik. Pertumbuhan bakteri akan optimal ketika jumlah nutrisi yang tersedia dalam media mendukung, ketika jumlah nutrisi dalam media mulai berkurang maka akan terjadi kompetisi dengan mikroba lain sehingga mengakibatkan jumlah mikroba menurun. Koesoemawardani (2013) juga melaporkan rusip dengan starter campuran Streptococcus, Lactococcus dan Leuconostoc sebanyak $2 \%$ lebih baik daripada rusip spontan dengan kriteria total bakteri asam laktat 12,37 log CFU/g, total mikroba 5,94 log CFU/g, pH 5,69 dan total asam laktat 5,04\%. Hal ini diperkuat pernyataan Buckle et al. (2009) bahwa pertumbuhan bakteri akan optimal ketika jumlah nutrisi yang tersedia dalam media mendukung, ketika jumlah nutrisi dalam media mulai berkurang maka akan terjadi kompetisi dengan mikroba lain sehingga mengakibatkan jumlah mikroba menurun. Penurunan jumlah total mikroba berkaitan dengan kondisi produk yang semakin asam akibat produksi asam laktat oleh bakteri asam laktat.

\section{Nilai total asam laktat dan $\mathrm{pH}$}

Total asam laktat perlakuan A mengalami peningkatan dari 0,86 menjadi 3,98\% (sebesar 3,12\%), perlakuan B dari 0,94 menjadi 3,84\% (sebesar $3,02 \%$ ) dan perlakuan $\mathrm{C}$ dari 0,82 menjadi $3,58 \%$ (sebesar 2,76\%). Peningkatan total asam selama proses fermentasi rusip diduga karena adanya pe- ningkatan jumlah BAL yang merombak gula menjadi asam laktat. Wardani et al. (2017) menyatakan bahwa peningkatan konsentrasi starter 1-5\% meningkatkan jumlah total mikroba dan menurunkan $\mathrm{pH}$ sampai akhir fermentasi.

Utami (2016) melaporkan total asam laktat rusip meningkat dari 0,63 menjadi 2,02\% (sebesar $1,39 \%$ ) dan 0,49 menjadi $1,48 \%$ (sebesar 0,99\%) masing-masing dengan penambahan starter tunggal SK(5) 10 dan 5\%. Kusmarwati et al. (2011) juga mengungkapkan total asam laktat meningkat dari 1 menjadi $2 \%$ dengan starter $P$. acilactici $\mathrm{F}-11$ dengan garam $10 \%$ selama 12 hari. Hasil penelitian ini menunjukkan bahwa penggunaan starter kombinasi BAL memberikan peningkatan nilai total asam laktat lebih besar $(2,76-3,98 \%)$ dibandingkan dengan penggunaan starter tunggal (0,99-2,00\%). Tingginya asam laktat yang dihasilkan diduga memberikan kontribusi terhadap rasa dan sifat antimikrobanya. Hal ini diperkuat dengan pernyataan Afriani (2010), bahwa kecepatan terbentuknya asam laktat dan tinggi rendahnya kadarasam laktat bergantung pada jumlah, jenis starter dan kemampuan starter dalam membentuk asam laktat. Grafik hubungan total asam dan $\mathrm{pH}$ disajikan pada Gambar 2.

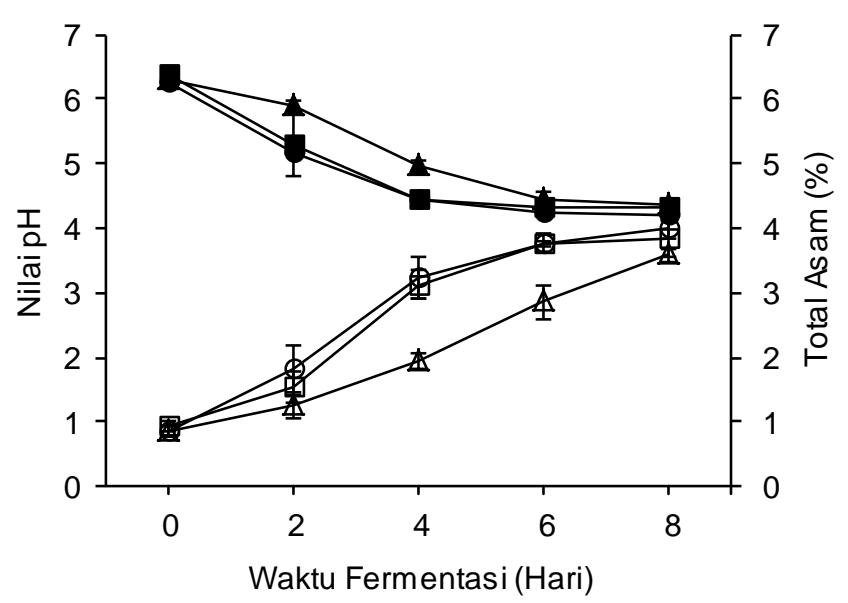

Gambar 2. Perubahan nilai $\mathrm{pH}$ dengan penambahan starter $\mathrm{A}(\bullet), \mathrm{B}(\boldsymbol{\bullet}), \mathrm{C}(\boldsymbol{\Delta})$ dan total asam laktat $A(\circ), B(\square)$ dan $C(\Delta)$

Bakteri asam laktat digunakan dalam makanan fermentasi karena kemampuannya untuk melakukan metabolisme gula dan membuat produk akhir berupa asam laktat dan asam lainnya. Desniar (2012) juga melaporkan bahwa Lactobacilus plantarum SK (5) merupakan bakteri penghasil asam organik dengan jumlah banyak dan didominasi oleh asam laktat dan asam asetat.

Perubahan total asam laktat erat hubungannya dengan $\mathrm{pH}$. Kenaikan total asam selalu berbanding terbalik dengan penurunan nilai $\mathrm{pH}$. Nilai $\mathrm{pH}$ rusip semua perlakuan kombinasi BAL mengalami penurunan selama fermentasi. Penurunan nilai $\mathrm{pH}$ perla- 
kuan A dari 6,28 menjadi 4,20 (sebesar 2,08), perlakuan B dari 6,35 menjadi 4,31 (sebesar 2,04), serta perlakuan C dari 6,29 menjadi 4,37 (sebesar 1,92). Penelitian Kusmarwati et al. (2011) membuktikan terjadi penurunan $\mathrm{pH}$ pada fermentasi 12 hari dengan starter Pediococcus acidilactici dari 6,21 menjadi 5,34 (sebesar 0,87 ). Nilai $\mathrm{pH}$ rusip pada penelitian ini lebih rendah, yaitu berkisar 6,28 menjadi 4,20 (penurunan sebesar 2,08). Rendahnya nilai pH disebabkan kemampuan starter BAL yang memiliki jenis dan kemampuan menghasilkan jumlah asam laktat yang berbeda. Semakin tinggi nilai total asam yang dihasilkan maka semakin rendah pula nilai $\mathrm{pH}$ pada produk. Perubahan nilai $\mathrm{pH}$ juga terjadi karena pemecahan senyawa $\mathrm{NaCl}$ yang terurai menjadi molekul-molekul penyusunnya yaitu ion $\mathrm{Na}^{+}$dan $\mathrm{Cl}^{-}$.lon $\mathrm{Na}^{+}$sangat dibutuhkan oleh bakteri asam laktat sebagai salah satu faktor pendukung pertumbuhannya. lon-ion $\mathrm{Cl}^{-}$menstabilkan diri dengan gugus $\mathrm{H}^{+}$dan menyebabkan suasana lingkungan menjadi asam karena terbentuknya senyawa $\mathrm{HCl}$ (Desniar et al., 2009).

\section{Asam amino bebas}

Uji kualitatif asam amino bebas menggunakan pereaksi ninhidrin untuk menentukan terdapatnya asam amino bebas dalam suatu bahan, bila bereaksi dengan gugus amino pada asam amino bebas membentuk senyawa berwarna ungu, jika bereaksi dengan prolin dan hidroksiprolin akan berwarna kuning. Kemudian sampel diukur menggunakan spektrofotometer. Semakin pekat warna ungu maka nilai absorbannya semakin tinggi. Perubahan nilai absorbansi asam amino bebas disajikan pada Gambar 3 .

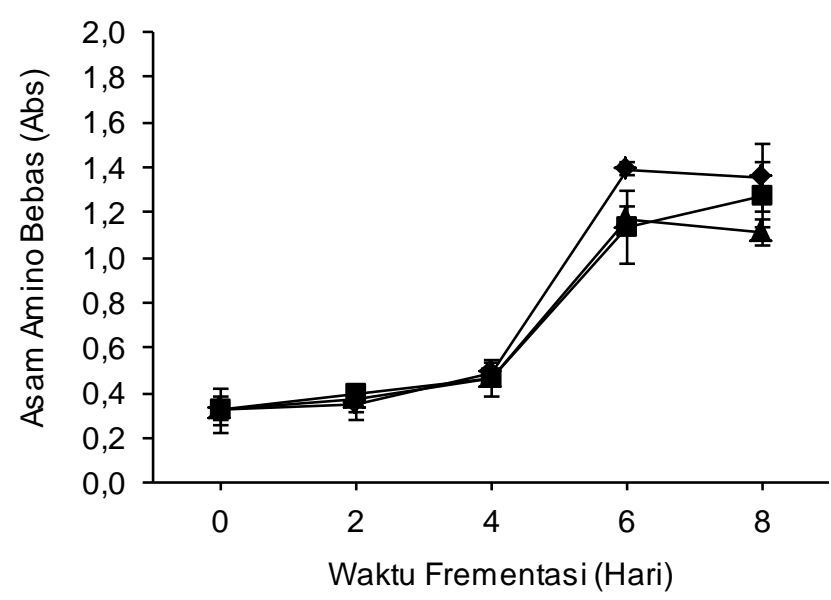

Gambar 3. Nilai absorbansi asam amino bebas dengan penambahan starter $A(\bullet), B(\bullet)$, $\mathrm{C}(\boldsymbol{\Delta})$

Nilai absorbansi pada semua perlakuan di hari ke-0 sebesar $0,320 \pm 0,10$. Perubahan nilai asam amino bebas rusip pada semua kombinasi BAL semakin meningkat hingga hari ke-6, yaitu pada perla- kuan A sebesar 1,39 $\pm 0,02$, perlakuan $B$ sebesar $1,13 \pm 0,17$ dan perlakuan $C$ sebesar $1,17 \pm 0,06$. Aktivitas pemecahan protein menjadi asam amino bebas paling tinggi pada perlakuan kombinasi A. Ricci et al. (2010) menyatakan pemecahan protein menjadi peptida dan asam amino bebas selama fermentasi disebabkan oleh aktivitas proteolitik dari bakteri tersebut. Aktivitas proteolitik dari bakteri akan meningkat seiring dengan meningkatnya jumlah sel bakteri di dalam suatu media pertumbuhan dan akan menurun ketika bakteri mulai memasuki fase lag dan kematian.

\section{Kadar garam ( $\mathrm{NaCl})$ rusip}

Hasil analisis menunjukkan produk akhir rusip semua perlakuan memiliki kadar garam berkisar $5,34 \pm 0,01-5,43 \pm 0,05 \%$. Gula aren sebagai bahan tambahan pada pembuatan rusip terbukti mengan-

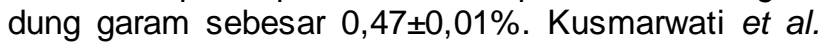
(2011) dan Koesoemawardani (2009) melaporkan bahwa penggaraman yang tinggi tidak efektif dalam menurunkan $\mathrm{pH}$. Hal ini disebabkan bakteri asam laktat dalam produk tidak mampu tumbuh bekerja secara optimal karena garam akan menghambat enzim proteolitik.

Permasalahan yang lain dalam pembuatan rusip adalah kadar garam yang digunakan sampai saat ini mencapai $10-25 \%$ dan yang terserap pada tubuh ikan sebesar 6-18\%. Kadar garam rusip umumnya masih tergolong tinggi dan dapat memicu hipertensi jika dibadingkan batas asupan sebesar $<5 \%$ atau $5 \mathrm{~g} /$ hari. Oleh karena itu penggunaan kultur starter dapat membantu fungsi dari garam dalam menekan pertumbuhan bakteri pembusuk. Hal ini terbukti dengan adanya penambahan kombinasi starter BAL probiotik dapat menurunkan kadar garam yang digunakan dalam proses pembuatan rusip dan tetap menghasilkan rusip dengan mutu baik.

Berdasarkan karakteristik kimia dan mikrobiologis, rusip terpilih adalah kombinasi perlakuan A (Lactobacilus plantarum SK(5) dan Lactobacilus plantarum NS(5)). Rusip terpilih menghasilkan total $\mathrm{BAL}$ yang tinggi pada hari ke-2 sebesar 9,25 log $\mathrm{CFU} / \mathrm{g}$, diikuti dengan total asam laktat tertinggi se-

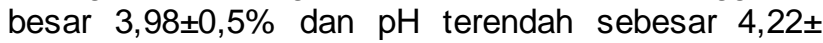
0,02 selama delapan hari fermentasi. Rusip mengandung senyawa asam asetat dan asam laktat yang tinggi, memiliki $\mathrm{pH}$ rendah dan kadar garam rendah. Menurut Sastra (2008), asam laktat yang dihasilkan bakteri laktat dengan nilai pH (keasaman) 3,4-4 cukup untuk menghambat sejumlah bakteri perusak dan pembusuk bahan pangan. Semakin asam rasa produk rusip menunjukkan bahwa semakin banyak konsentrasi asam yang dihasilkan oleh starter BAL yang terkandung. Analisis komposisi asam amino dilakukan pada rusip terpilih. 


\section{Komposisi Asam Amino Rusip}

Total asam amino rusip dengan starter perlakuan $A$ sebesar $12,36 \mathrm{~g} / 100 \mathrm{~g}$. Kandungan asam amino rusip terpilih lebih tinggi dibandingkan penelitian Utami (2016) dan Khairi (2014). Perbedaan total asam amino diduga adanya pengaruh terhadap penggunaan starter yang ditambahkan. Komposisi asam amino rusip terpilih (Lactobacillus plantarum SK(5) dan Lactobacillus plantarum NS(5)) disajikan pada Tabel 2.

Pada penelitian ini, asam glutamat dan glisin termasuk asam amino non esensial dominan dalam rusip. Asam glutamat merupakan asam amino yang sangat dominan yaitu $1,97 \mathrm{~g} / 100 \mathrm{~g}$ yang diperoleh dari glutamin. Gugus amida yang terdapat pada molekul glutamin dapat diubah menjadi gugus karboksilat melalui proses hidrolisis dengan asam atau basa, dimana proses hidrolisis yang terjadi melibatkan asam yang dihasilkan oleh bakteri asam laktat. Bakteri asam laktat merupakan mikrobia yang banyak menghasilkan asam glutamat. Zareian et al. (2012) melaporkan bahwa L. plantarum merupakan produsen penghasil asam glutamat tertinggi. Bakteri asam laktat menjadi pilihan yang paling efisien dalam memproduksi asam glutamat yang dihasilkan dari produk fermentasi sehubungan dengan biosintesa alami asam glutamat. Harli (2008) melaporkan asam glutamat dapat menciptakan rasa gurih (umami) dan juga bermanfaat untuk menahan keinginan konsumsi alkohol berlebih, mempercepat penyembuhan luka pada usus, meningkatkan kesehatan mental serta meredam emosi. Kandungan glisin pada rusip sebesar $1,03 \mathrm{~g} / 100 \mathrm{~g}$. Glisin merupakan asam amino yang dapat menghambat proses dalam otak yang menyebabkan kekakuan gerak seperti pada multiple sclerosis.

Arginin dan leusin termasuk asam amino esensial yang dominan dalam rusip. Arginin adalah asam amino yang dibentuk di hati dan beberapa diantaranya terdapat dalam ginjal. Arginin bermanfaat untuk meningkatkan daya tahan tubuh atau produksi limfosit, meningkatkan pengeluaran hormon pertumbuhan (HGH) dan meningkatkan kesuburan pria. Leusin merupakan asam amino yang bekerja untuk memacu fungsi otak, menambah tingkat energi otot, membantu menurunkan kadar gula darah berlebih, serta membantu penyembuhan tulang, jaringan otot dan kulit (Harli, 2008).

Zhang et al. (2010) menyatakan bahwa perubahan biokimia seperti protein menjadi asam amino dan lemak menjadi asam lemak selama proses fermentasi berperan penting dalam menghasilkan senyawa flavor dan aroma. Hal ini berhubungan dengan proses fermentasi sangat kompleks dan beragam, tergantung pada bahan baku (daging, bumbu dan kultur starter) dan teknologi (penggaraman, fermentasi, ripening drying, proses fermentasi dan drying) yang digunakan pada produk daging.

Rusip dimanfaatkan sebagai bahan tambahan atau bumbu masakan, rusip juga merupakan suatu variasi olahan ikan teriyang dapat disimpan dalam waktu cukup lama, bakteri asam laktat probiotik yang terkandung di dalam rusip bisa langsung bekerja terhadap sistem pencernaan tubuh dibandingkan dengan ikan teri tanpa proses fermentasi dengan BAL probiotik.

Tabel 2. Profil asam amino rusip terpilih L. plantarum SK(5) dan NS(5)

\begin{tabular}{lccc}
\hline \multicolumn{1}{c}{ Asam Amino Rusip } & L. plantarum SK(5) dan NS(5) $5 \%(\mathrm{~g} / 100 \mathrm{~g})$ & $\begin{array}{c}\text { L. plantarum SK(5) } \\
5 \%{ }^{*}(\mathrm{~g} / 100 \mathrm{~g})\end{array}$ & $\begin{array}{c}\text { Rusip komersial } \\
{ }^{* *}(\mathrm{~g} / 100 \mathrm{~g})\end{array}$ \\
\hline Asam aspartat(Asp) & 0,82 & 0,77 & 1,04 \\
Asam glutamat (Glu) & 1,97 & 1,36 & 2,30 \\
Serina (Ser) & 0,45 & 0,53 & 0,36 \\
Glisina (Gly) & 1,03 & 0,89 & 0,58 \\
Alanina (Ala) & 0,21 & 0,67 & 0,67 \\
Tirosina (Try) & 0,40 & 0,60 & 0,39 \\
Prolina (Pro) & 0,88 & 0,47 & 0,40 \\
Sisteina (Cys) & 0,24 & - & 0,10 \\
\hline Total asam amino non esensial & 6,00 & 5,29 & 5,86 \\
\hline Histidina (His) & 0,26 & 0,42 & 0,40 \\
Arginina (Arg) & 1,21 & 0,69 & 0,35 \\
Metionina (Met) & 0,32 & 0,38 & 0,36 \\
Valina (Val) & 0,54 & 0,60 & 0,66 \\
Fenilalanina (Phe) & 0,39 & 0,87 & 0,46 \\
Isoleusina (Ile) & 0,26 & 0,59 & 0,56 \\
Leusina (Leu) & 1,52 & 1,01 & 0,88 \\
Lisina (Lys) & 1,41 & 0,93 & 1,04 \\
Treonina (Thr) & 0,45 & 0,70 & 0,54 \\
\hline Total asam amino esensial & 6,36 & 6,20 & 5,25 \\
\hline Total asam amino & 12,36 & 11,49 & 11,11 \\
\hline Keterangan: ${ }^{*}$ Utami (2016); ${ }^{* *}$ Khairi et al.(2014) & & &
\end{tabular}




\section{KESIMPULAN}

Penambahan kombinasi starter BAL probiotik memberikan pengaruh terhadap perubahan kimia dan mikrobiologis rusip selama fermentasi delapan hari. Karakteristik mikrobiologis dan kimia meliputi total BAL 7,64-9,24 log CFU/gr, total asam titrasi 0,86-3,98\%, pH 4,22-6,36 dan kadar garam 5,34$5,44 \%$. Rusip terpilih yaitu kombinasi $L$. plantarum SK(5) dengan L. plantarum NS(5). Rusip terpilih mengandung total asam amino sebesar $12,37 \mathrm{~g} / 100 \mathrm{~g}$ yang didominasi oleh asam glutamate sebesar 1,97 $\mathrm{g} / 100 \mathrm{~g}$.

\section{DAFTAR PUSTAKA}

Afriani. 2010. Pengaruh penggunaan starter bakteri asam laktat Lactobacillus plantarum dan Lactobacillus fermentum terhadap total bakteri asam laktat, kadar asam dan nilai $\mathrm{pH}$ dadih susu sapi. J IImiah IImu-ilmu Peternakan 13: 279-285.

Afrianto $E$, Liviawaty $E$, Suhara $O$, Hamdani $H$. 2014. Pengaruh suhu dan lama blanching terhadap penurunan kesegaran filet tagih selama penyimpanan pada suhu rendah. J Akuatika 5: 45-54.

[AOAC] Association of Official Analytical Chemist. 2005. Official Method of Analysis of the Association of Official Analytical Chemist. Chapter 35.1.29 No Methode 969.33. Association of Official Analytical Chemist Inc, Virginia (US).

[BSN] Badan Standarisasi Nasional. 2009. SNI 2354.8:2009. Cara Uji Kimia bagian 8: Penentuan Kadar Total Volatile Basses Nitrogen (TVBN) dan Troimetil Amin Nitrogen (TMA-N) pada Produk Perikanan. Badan Standardisasi Nasional. Jakarta.

Bosch M, Fuentes MC, Audivert S, Bonachera MA, Peir'o S, Cune J. 2014. Lactobacillus plantarum CECT 7527, 7528 and 7529: probiotic candidates to reduce cholesterol levels. J Sci Food Agric 94: 803-809. DOI: 10.1002/jsfa.6467.

Buckle KA, Edwards RA, Fleet $\mathrm{GH}$, Wooton $\mathrm{M}$. 2009. Ilmu Pangan. Purnomo $\mathrm{H}$ dan Adiono, penerjemah. Terjemahan dari: Food Science. 13-71. UI Press, Jakarta.

Cheng JH, Sun DW, Zeng XA, Pu HB. 2014. Nondestructive and rapid determination of TVB-N content for freshness evaluation of grass carp (Ctenopharyngodon idella) by hyperspectral imaging. Innov Food Sci Emerg 21:179-187. DOI: 10.1016/j.ifset.2013.10.013.

Desniar D, Poernomo D, Wijatur W. 2009. Pengaruh konsentrasi garam pada peda ikan kembung
(Rastreliger sp.) dengan fermentasi spontan .J Pengolahan Hasil Pertanian 12: 73-87.

Desniar, Iriani S, Retno SS. 2012. Perubahan parameter kimia dan mikrobiologi serta isolasi bakteri penghasil asam selama fermentasi bekasam ikan mas (Cyprinus carpio). J Pengolahan Hasil Perikanan Indonesia 15: 232-239.

Desniar, Setyaningsih I, Purnama YI. 2016. Penapisan dan produksi antibakteri Lactobacillus plantarium NS (9) yang diisolasi dari bekasam ikan nila atin. J Pengolahan Hasil Perikanan Indonesia 19: 132-139. DOI: 10.17844/jphpi.v19i2.134 58.

Françoise L. 2010. Occurrence and role of lactic acid bacteria in seafood products. Food Microbiol 27: 698-709. DOI: 10.1016/j.fm.2010.05.0 16.

Gomes AC, Bueno AA, de Souza RGM, Mota JF. 2014. Gut microbiota, probiotics and diabetes. Nutr J 13: 1-13. DOI: 10.1186/1475-2891-1360.

Harli M. 2008. Asam amino esensial.http://www. supamas.com. [24 Januari 2018]

Khalafalla FA, Ali FHM, Hassan ARHA. 2015. Quality improvement and shelf-life extention of refrigerated nila tilapia (Oreochromis niloticus) fillets using natural herbs. Beni-Suef University J Basic Appl Sci 4: 33-40. DOI: 10.1016/j.bjbas. 2015.02.005.

Khairi INBM, Huda N, Abdullah WNW, Al-Karkhi AFM. 2014. Protein quality of fish fermented product: Budu and rusip. Asia Pacific J Sustain Agric Food Energ 2: 17-22.

Khan H, Flint S, Yu PL. 2010. Enterocins in food preservation. Int $\mathrm{J}$ Food Microbiol 141: 1-10. DOI: 10.1016/j.ijfoodmicro.2010.03.005.

Koesoemawardani D, Yuliana N. 2009. Karakteristik rusip dengan penambahan kultur kering Streptococcus sp. J Sains Teknol Indonesia 11: 205 211.

Koesoemawardani D, Rizal S, Tauhid M. 2013. Perubahan sifat mikrobiologi dan kimiawi rusip selama fermentasi. Agritech 33: 265-272.

Kurnasih T. 2016. Fermentasi Rusip menggunakan Starter BAL Lactobacillus plantarum (SK5) dengan Konsentrasi Berbeda [Skripsi]. Bogor: Fakultas Perikanan dan IImu Kelautan, Institut Pertanian Bogor.

Kusmarwati A, Heruwati ES, Utami T, Rahayu ES. 2011. Pengaruh penambahan Pediococcus acidilactici F-11 sebagai kultur starter terhadap kualitas rusip teri (Stolephorus sp.) .J Pascapanen Bioteknol Kelautan Perikanan 6: 13-26. 
Liu S, Han Y, Zhou Z. 2011. Lactid acid bacteria in traditional fermented Chinese foods. Food Res Int 44: 643-651. DOI: 10.1016/j.foodres.2010. 12.034

Nurnaafi A, Setyaningsih I, Desniar. 2015. Potensi probiotik bakteri asam laktat asal bekasam ikan nila. J Teknol Industri Pangan 26: 109-114. DOI: 10.6066/jtip.2015.26.1.109.

Ricci I, Artacho R, Olalla M. 2010. Milk protein peptides with angiotensin I-converting enzyme inhibitory (ACEI) activity. Crit Rev Food Sci Nutr 50: 390-402. DOI: 10.1080/104083908023041 98.

Sastra W. 2008. Fermentasi Rusip [Skripsi]. Bogor: Fakultas Perikanan dan IImu Kelautan, Institut Pertanian Bogor.

Utami AN. 2016. Karakteristk Rusip dengan Konsentrasi Starter Lactobacillus plantarum (SK5) yang Berbeda [Skripsi]. Bogor: Fakultas Perikanan dan IImu Kelautan, Institut Pertanian Bogor.
Wardani SK, Cahyanto MN, Rahayu ES, Utami T. 2017. The effect of inoculums size and incubition temperature on cell growth, acid production and curd formation during milk fermentation by Lactobaciluus plantarum Dad 13. Int Food Res J 24: 921-926

Zareian M, Ebrahimpour A, Abu Bakar F, Mohamed AKS, Forghani B, Ab-Kadir MS. 2012. A glutamic acid-producing lactic acid bacteria isolated from malaysian fermented foods. Int $\mathrm{J}$ Mol Sci 13: 5482-5497. DOI: 10.3390/ijms13055482.

Zhang W, Xiao S, Samaraweera H, Lee EJ, Ahn DU. 2010. Improving functional value of meat products. Meat Sci 86: 15-31. DOI: 10.1016/j.meat sci.2010.04.018.

Zhang Y, Zhang H. 2013. Microbiota associated with type 2 diabetes and its related complications. Food Sci Hum Wellness 2: 167-172. DOI: 10.10 16/j.fshw.2013.09.002. 